\title{
JUST Revisited: Panchronic and Contrastive Insights
}

\author{
Clara MOLINA* \\ MANUELA ROMANO \\ Universidad Autónoma de Madrid
}

Received: 10 May 2011 / Accepted: 13 June 2011

\begin{abstract}
Contrastive studies of cognate pragmatic markers involving modality have become increasingly salient in recent times. In describing semantic and discursive differences in different languages and language families, these studies are paving the way for a better understanding of grammaticalization, pragmaticalization and (inter)subjectification paths. The present paper aims at contributing to the discussion by means of providing a synchronic and diachronic account of the marker JUST that combines semasiological and onomasiological insights. As thoroughly described in previous studies, JUST is a complex polycentric category in which overlapping nuances have been activated over time. In English and in other languages, the diachronic evolution of JUST involves an increasing semantic expansion from scalar to subjectified meanings and an increasing restriction in grammatical flexibility. However, polysemization and the emergence of grammaticalized readings seem to have gone further in English than in other languages. The present study, situated within the emerging field of panchronic cross-linguistic research on discourse markers, aims at ascertaining why.
\end{abstract}

KEYWORDS: pragmatic markers, grammaticalization, semasiology, onomasiology, panchronic, crosslinguistic, JUST.

\section{RESUMEN}

El estudio contrastivo de los marcadores pragmáticos de modalidad ocupa una posición central en el campo de la gramaticalización, la pragmaticalización y la (inter)subjetivización, ya que permite trazar rutas de cambio a través de la descripción de peculiaridades semánticas y discursivas en distintas lenguas y familias lingüísticas. Este trabajo contribuye al debate ofreciendo un análisis semasiológico y onomasiológico del marcador JUST en sincronía y diacronía. Se trata de una categoría policéntrica en la que se han ido activando lecturas cruzadas a lo largo del tiempo. Su evolución está marcada, tanto en inglés como en otras lenguas, por una expansión semántica cada vez mayor, transitando desde lecturas escalares hacia lecturas subjetivizadas, y por una flexibilidad gramatical cada vez menor. No obstante, la polisemización y la gramaticalización parecen haber llegado más allá en inglés que en otras lenguas. Este trabajo, situado en el campo emergente de la investigación pancrónica y translingüística de los marcadores discursivos, pretende explicar la razón.

PALABRAS CLAVE: marcadores pragmáticos, gramaticalización, semasiología, onomasiología, pancronía, translingüístico, JUST.

\footnotetext{
*Address for correspondence: Clara Molina and Manuela Romano, Universidad Autónoma de Madrid, Facultad de Filosofía y Letras, Departamento de Filología Inglesa, 28049 Madrid, Spain. E-mail: clara.molina@uam.es; manuela.romano@uam.es
} 


\section{JUST IN ENGLISH TODAY}

Over the last two decades, discourse markers have become a distinct field of linguistic enquiry (Abraham, 1991; Aijmer, 2002; Aijmer \& Simon-Vandenbergen, 2003, 2004, 2006; Athanasiadou, Canakis \& Cornilie, 2006; Blakemore, 2002; Brinton, 1996; Fischer, 2000, 2006; González, 2004; Jucker \& Ziv, 1998; König, 1991; Lenk, 1998; Martín-Zorraquino \& Montolío, 1998; Mosegaard Hansen, 1998; Pons, 2008; Portolés, 2001; Schiffrin, 1987; Siepmann, 2005; Sweetser, 1990; Traugott \& Dasher, 2002) in which several phenomena coexist, as evidenced by the lack of agreement on the classification and naming of these elements. The particle JUST belongs to a broad set of -mostly oral- pragmatic markers (according to Aijmer, 2002:153, in the rank-list of the most frequent words in the LondonLund Corpus, JUST occupies rank 54, placing it among the most frequent words in the spoken language, while it is not among the most frequent 100 written words in either the LOB Corpus or the Brown Corpus) that serve interpersonal functions (in this case, the expression of speaker's involvement, stance or affect), as opposed to canonical discourse markers, that signal textual relations between clauses. However, the distinction between both sets is not clear-cut, since the textual and interpersonal function can co-occur in the same discourse, and the prevalence of one function over the other is a matter of prototypicality that springs from the potential meanings of the particle (Aijmer, 2002:39).

In spite of the attention it has received in the literature (Aijmer, 1985, 2002; Cohen, 1969; Erman, 1997; Gibbs \& Matlock, 2001; Kishner \& Gibbs, 1996; Lee, 1987, 1991; Leeman, 2004; Nevalainen, 1991; Traugott, 1988, 1990; Wierzbicka, 1991), the contemporary semantics of English JUST remains controversial and a number of questions still lack an undisputed answer: How many readings exist within the category and how are they related to one another? Have those readings emerged because of specific contextual constraints or because the semasiological profile of the marker has invited the activation of senses? Is there a single core meaning and if so, which one is it? An unquestioned response to these queries would still leave one question unanswered: Why does the category seem to have developed more readings in English than in other languages? An inspection of contemporary dictionaries reveals that the semantic profile of JUST displays a much richer degree of polysemization in English than in other languages, as many of the twenty-five nuances recorded in English are not attested in many of the cognate terms. The analysis of nuances allows identifying more encompassing senses within which individual readings may be ingrained, but nonetheless the overall number of senses remains larger in English than in languages such as Dutch, French, German, Italian, Portuguese, Rumanian, Spanish or Swedish. A sketch of the contemporary semantics of JUST will introduce the discussion. The BYU-BNC British National Corpus (Davies, 2011) is the source for the contemporary examples in English throughout the paper, excerpted in the main from samples of contemporary spoken discourse from classrooms and tutorials. 
The pragmatic marker JUST stresses the notion of preciseness, a central meaning which, to our mind, branches out in two axes, downtoning and uptoning, under which the many readings of JUST find room. The downtoning axis comprises attenuating readings that emerge from the early uses of the term as a restrictive scalar specificatory adverb presented in section 2. This axis, we argue, includes readings for (1) the specification of time and location; (2) restriction; (3) minimization and (4) possibility, in context of terms like might and may, as in the examples 1 to 4 below.

1. Which has one main assumption erm that all the things I've JUST mentioned about pronunciation and speech rates and things, erm they all occur in order to encourage more interaction between the two speakers.

2. Then another thing was unstressed ing. That erm instead of saying ng they pronounced it as JUST $n$. In words such as building graduating and nothing it would JUST be an $n$ on the end like buildin graduatin. Erm They dropped the final consonant.

3. So Mike have you got your project sorted out? Well it's more or less in hand, yeah. What what you're doing? Yeah With Stewart? yeah. So is it JUST a continuation of what you've done anyway? Well more or less but we weren't amused at any of the results so Oh I see right. I've got to start again.

4. He is going to be talking to the MA students er taking Economic Development and Policy Analysis and his topic there is comparing income inequality and poverty in Europe erm so if you, you know, if you are free tomorrow at two it JUST might be interesting to go along to, feel free to go to B seventy four tomorrow at two o'clock.

In turn, the uptoning axis comprises intensive readings that emerge from the early uses of JUST as a scalar specificatory adverb within the domain of exactness. This axis includes readings for expressing (5) exactitude and (6) emphasis, as well as emergent discursive uses for (7) politeness and (8) agreement, as in examples 5 to 8. The last reading, not attested in other languages, finds room in British spoken English as a marker of complete agreement with what someone has said, especially a criticism: isn't s/he just, doesn't s/he just? (http://www.macmillandictionary.com/thesaurus/british/just\#just_4)

5. Unem the level of unemployment is subsumed between, well, within the time it takes to get a job, and also the probability of, of getting a job. Alright. So this sort of, even that's JUST what the Harrison model erm, tells us, right, so that's, unemployment rates are, are virtually erm, unimportant in the migrant's decision. 
6. What happens to the like project? It got cancelled. Cancelled It got cancelled? Oh right, didn't hear that then. There Oh that's why we're not doing it any more, so what do we have to do instead of having to do an essay? JUST an essay. Oh, they decided not to give us quite so much work? Mm. Oh right.

7. Can I JUST ask a question? Mm. Right, you said that the reason is, there's lack of information so, that's why people migrate, because they don't realize they're not going to get a job.

8. By then Mala and I were sunk into our pouch-seats, awash with laughter. Or anyway I was, while Mala struggled to keep her giggles from swamping all of her outrage. "Foul little lizard!" she said, half-choking. "Wasn't he JUST" I agreed, mopping my eyes.

The notion of restriction has traditionally been favoured in the literature as the single prototypical core of the category: "clearly the primary semantic function of JUST, as Brown and Levinson point out, is to express a restrictive meaning. What is interesting about the particle, however, [...] is that the type of restrictive meaning which it expresses varies in character from one example to another. This raises the question of whether we are dealing with a polysemous item or whether the differences in meaning derive from the interaction between the particle and the other semantic elements with which it enters into construction" (Lee, 1987:378). However, an alternative understanding of JUST as a polycentric category in which intensification coexists with restriction in the organization of the category is proposed here, which accounts for the subjectified readings that have emerged as well in languages in which restrictive nuances do not seem salient. This position is also endorsed by Aijmer (2002:22), who claims that "discourse particles are polysemous items whose meanings can be related to each other in a motivated way, for example as extensions from a prototype. This is compatible with the diachronic model of grammaticalization (pragmaticalization) in which pragmatic functions are derived from a propositional meaning via certain paths and on the basis of pragmatic principles. This development may be supported by the core meaning of the particle [...] JUST is restrictive or exclusive in addition to its intensifying meaning as a discourse particle".

As for the reasons for the activation of particular readings, the literature often mentions the context as a trigger, since the adverb is thought to adopt the meaning of the specific word classes with which it interacts. More often than not, however, only syntagmatic collocational patterns are taken into account, as in Gibbs and Matlock (2001:220), for whom

JUST derives its comparative meaning from prepositions; its exact meaning from conjunctions; its specificatory meaning from prepositions; its emphatic meaning from 
adjectives; its depreciatory meaning from verbs; and its restrictive meaning from nouns $[\ldots]$ This would suggest [...] that JUST gains its meaning by its frequent co-occurrence with specific types of words.

Such a narrow approach to context demotes the internal articulation of the category to a peripheral position and remains inadequate for taking decisions. For this reason, an expanded view of context that accommodates the behaviour of the marker on the paradigmatic axis, both synchronically and diachronically, seems to afford the basis for a more accurate explanation of the semantic structure of JUST. In this way, our study brings in a dimension, the paradigmatic one, which has tended to be neglected in approaches to grammaticalization that have rather focused on the reanalyses of the various syntagmatic environments (constructions) in which grammaticalized items occur. At the same time, our panchronic insight into the history of the term in English not only provides the setting for an expanded view of context; it also allows tracing intensive (uptoning) readings together with restrictive (downtoning) ones back to the time in which JUST was introduced as a loanword from French.

\section{DIACHRONIC EVOLUTION OF JUST}

JUST enters the English language at the turn of the $15^{\text {th }}$ century as an adjective borrowed from the medieval French adjective JUSTE, ultimately from the Latin adjective IUST meaning 'righteous, legitimate'. From then on, as charted in Table 1 (based on Nevalainen, 1991; Oxford English Dictionary citations and Traugott, 1988, 1990), adverbial readings become prevalent within the domains of scalarity and discursive subjectivity. Already in the $15^{\text {th }}$ century, JUST is used as an adverb of manner meaning 'justly, honourably'. This reading is soon dropped from the language, but the adverb of manner remains as a scalar particle ("a particle that brings into play alternatives to the meaning or value of the focus constituent", Traugott, 1988:131) meaning 'exactly'. Shortly afterwards, a specificatory reading for measurement and location (meaning 'exactly, precisely') emerges. These two scalar meanings, which can be explained through an invited inference ('what is just or justly done is done in the precise or right way'), rapidly spread during Early Modern English times.

During the first half of the $17^{\text {th }}$ century, the expansion of the notion of scalarity (which includes restrictive and exact readings) continues with the appearance of temporal specificatory uses of the adverb. The first temporal readings arise in contexts where JUST has specific time expressions as its focus (she left just then). From there, the change from 'exact time of utterance' to 'deictically proximal time or immediate future' (she's just leaving) is not difficult to infer. Afterwards, the shift from 'immediate future' to 'immediate past' takes place in constructions with no overt time expression (she just left), in the cline from more objective temporal meanings to more subjectified temporal meanings. As Traugott (1988:134) states, 
"the particle JUST [...] injects the speaker's point of view into the proposition [...] The imposition of speaker point of view is particularly clear in the case of the downtoning JUST where the possibility of external verification by scientific instrument is out of the question, and the speaker is imposing a negative evaluation. We can therefore assume that the downtoner as well as the deictic temporal developed later than the scalar particle".

Restrictive readings emerge towards the end of the $17^{\text {th }}$ and beginning of the $18^{\text {th }}$ centuries and, simultaneously, more pragmatic meanings develop from the notion of scalarity present in the adverb of manner, the specificatory adverb of measurement and location, the specificatory temporal adverb and the exclusive adverb. The rise of pragmatic and subjectified meanings presents the following timeline: (1) the term is first attested as a downtoner towards the end of the $17^{\text {th }}$ century. According to Traugott (1988:139), this reading can also be explained as pragmatic inferencing, since JUST excludes the possibility of having a larger amount of something, which is negative within a society that prizes principles such as 'the more, the better'; (2) the first emphatic uses date from the first half of the $18^{\text {th }}$ century; and (3) contemporary corpora and dictionary data, but not the literature, record the recent developments of JUST as a pragmatic marker for politeness and agreement.

\begin{tabular}{|l|l|l|}
\hline ADJECTIVE & Manner & early $15^{\text {th }}$ century \\
\hline \multirow{4}{*}{ SCALAR ADVERB } & Specificatory - Manner & early $15^{\text {th }}$ century \\
\cline { 2 - 3 } & $\begin{array}{l}\text { Specificatory }- \text { Measurement and } \\
\text { location }\end{array}$ & $16^{\text {th }}$ century \\
\cline { 2 - 3 } & Specificatory - Time & $17^{\text {th }}$ century \\
\cline { 2 - 3 } $\begin{array}{l}\text { SUBJECTIFIED PRAGMATIC } \\
\text { MARKER }\end{array}$ & Restrictive & early $18^{\text {th }}$ century \\
\cline { 2 - 3 } & Downtoning & $18^{\text {th }}$ century \\
\cline { 2 - 3 } & Emphatic & $18^{\text {th }}$ century \\
\cline { 2 - 3 } & Marker of politeness & $20^{\text {th }}$ century \\
\cline { 2 - 3 } & Marker of agreement & $20^{\text {th }}$ century \\
\hline
\end{tabular}

Table 1: Diachronic rise of major nuances in English JUST

All in all, the diachronic evolution of JUST involves two converging trends: on the one hand, increasing polysemy, from one scalar reading in the early times (exact) to an array of senses in contemporary English which confirms the well-known universal path from concrete to abstract and from objective to subjective; and on the other, increasing grammatical restriction, that is, more contextual constraints, since JUST is no longer possible with a large number of collocations actually attested in early texts, as in the Oxford English Dictionary examples 9 to 12 below.

9. The gyaunt he hyttez, IUST to the genitals. (?a1400 Morte Arth. 1123)

He hit the giant, JUST at the genitals. 
10. Then ryseth the Sunne at fiue of the clocke IUST. (1574 Bourne Regim. for Sea Introd).

The sun rises at five o'clock JUST.

11. Iaq. Rosalinde is your loues name? Orl. Yes, IUST. (1600 I A.Y.K. iii. Ii. 281)

Rosalinde is your love's name? Yes, JUST.

12. You love to have your clothes hang JUST, sir. (1676 G. Etherege Man of Mode i. i).

You love to have your clothes hung JUST (in a close fitting way), sir.

As such, JUST becomes increasingly attached to specific collocational patterns associated with specific semantic facets, while discursive choices become increasingly restricted, and polysemization and pragmaticalization gain more and more ground over time. There is patchy evidence of the evolution of the term in other languages, since "the full-size native-speaker dictionaries, most bilingual dictionaries and the monolingual learner's dictionaries are all surprisingly patchy in their coverage of discourse markers" (Siepmann, 2005: 288) and the category has not received as much attention in the literature in other languages as in English. However, the available grounds allow suggesting that cognate forms in other languages should have followed a parallel development with regard to the one outlined for English, since the category displays similar meanings in a large number of languages, shifting from objective to subjectified readings. Leeman (2004) claims there has been a recent expansion of the use of JUSTE in French, evidenced by examples such as Tu es prête? Je ferme JUSTE les fenêtres et j 'arrive (just a second and I'm ready); C'est JUSTE un ami (not a date, don't get me wrong); or Je veux JUSTE te demander un service (that's it).

Complementary evidence comes from an ad hoc survey of the uses of cognates of JUST in various languages, which reveals similar expansion often not yet recorded in dictionaries. Our survey, conducted among international university lecturers and students of English language and linguistics, aimed at probing the translatability of polysemous categories while exploring whether contextual clues elicit the same readings of JUST in different languages. To this end, a questionnaire with examples from Gibbs and Matlock (2001) and Kishner and Gibbs (1996), with and without a disambiguating context, was distributed. The subjects were asked to translate the examples in the questionnaire into their first language, paraphrasing or providing a synonym for JUST, and to provide typical instantiations of the marker in their language. The hypothesis was that the divergence between the term in English and in other languages was not only a function of collocation with specific word classes, as often suggested in previous studies. If this had been the case, those clues would still have been present in disorderly presented examples, prompting an speedy understanding of the instances, which was not the case: even those instances that fitted neatly as best exemplars of a given category in the literature, ceased to do so and became 
outstandingly vague for informants once all examples were disarranged and mixed up in the questionnaire. Native and proficient speakers of English complained that, as they kept on thinking about the examples, an increasing number of meanings were activated at about the same time, and that a prosodic context was needed to elucidate meaning.

Not surprisingly, those readings not lexicalized in the language of some of the participants were the most difficult ones to translate, and the translations often departed expletively from immediate renderings of the cognate: swearwords and highly emotional, pragmatically loaded expressions were often chosen to accommodate uses of JUST not surfaced in other languages. The data provided by the participants constitute the source for examples 13 to 17 , which are a token of the incidence of pragmaticalization processes in JUST in various languages: contrast in Italian (13); a polite topic switch in Spanish (14); coincidence, and contrast with an assumption made elsewhere in context, in Dutch (15 and 16); and irony in Swedish (17).

13. 'Noné ora di pulire qui?' 'GIUSTO!' (cleaning up obviously not being what the interlocutor wants)

14. Yo JUSTO quería pedirte que... (introducing a probably unwelcome request)

15. Toen het begon te regenen had ik JUIST geen paraplu bij me (sudden shower and no umbrella)

16. Waarom doe je zoiets, terwijl je JUIST het goede voorbeeld moet geven? (improper behaviour rather than the expectable setting of the right example)

17. Han tillhör JUSTE inte de större snillena (someone not belonging precisely to the most intelligent)

None of the uses identified within the survey, however, include the expression of agreement identified in English. Language family belonging does not seem a plausible reason for the divergence, since similar developments, albeit at different paces, seem to be taking place in Romance and Germanic languages alike. Differences in the semasiological profile of the marker does not seem a cogent explanation either, since scalar specificatory and exclusive senses, as well as more subjectified uses, seem to be emerging in all languages, and it might be assumed that the more pragmatically discursive readings not yet present in some languages might be in the oven: "changes are always manifested in synchronic variation, and past changes can commonly be found in synchronic alternations, or attested in written records" (Andersen, 2001:208). The divergence nonetheless exists, and to our mind, a plausible guess as for why English JUST has acquired a distinct twist, becoming grammaticalized as a 
pragmatic marker at an earlier date than its cognates, is through interaction with other items within the same semantic space, that is, through onomasiological interface, as well as because of the impact of the socio-historical background of English.

\section{ONOMASIOLOGICAL AND SOCIO-HISTORICAL INSIGHTS}

The presence of distinct domains within JUST reveals a polycentric structure with more than one prototypical centre from which peripheral meanings develop, rather than a radial one in which readings spring from a single core. The most prototypical core, located within the domain of presuppositional terms (according to Traugott, 1990:505, "terms that presuppose, entail or implicate relations to a scale and that, at least in some of their meanings, express speaker attitudes") is supplemented with another important core, located within the domain of exclusive or focusing adverbs (Nevalainen, 1991). The delimitation of centres within the category, however, is not clear-cut, and Traugott after König (1988:132) proposes as many as three distinctions in the adverbial meanings of JUST, "synchronically coherent in that they bring to attention alternatives (allowed or disallowed) on an ordered scale": an exclusive scalar particle meaning 'precisely, only, simply'; a deictic temporal adverb meaning 'immediate future or past'; and a downtoner.

The notion of homeomorphism, applied in synergetic theory to describe the qualitative behaviour of gradual processes which show sudden discontinuities in their development (Bernárdez, 1995; Haken, 1977; Thom, 1972; Prigogine, 1983; Wildgen, 1994) may help further explain the structure of the category. The synergetic, self-regulative features displayed by grammaticalization processes are well described in complex systems theory, i.e., the ability to adapt to changes in the psycho-physical environment by means of changes within the system itself; regularity and stability; and the dependency on the initial conditions, which determines behaviour and a tendency to keep overall expenditure of energy at an optimalminimum state.

In being self-regulated, environment-dependent and beyond conscious control, grammaticalization stands out as a token of complexity that fits homeomorphism, and to our mind, the category of focusing adverbs is a paradigmatic example of a homeomorphic system. According to Nevalainen (1991), the category had fourteen members at the beginning of the Early Modern English period: alone, alonely, barely, but, exclusively, just, merely, one, only, purely, singly, simply, solely and uniquely. Over time, some members disappeared (one and alonely) while others were added (exclusively), and by the end of the Modern English period, the category had come to be restricted to six central members. Together with only, JUST was the most strengthened member of the category and, in absorbing many readings once expressed by other members, it became the centre of the onomasiological domain of exclusive or focusing adverbs. 
The interface described above accounts for our selection of the terms but and only for investigating whether mutual onomasiological interdependence over time explains the contemporary semantics of JUST. In addition, the terms right and very were selected for inspection, since they pertain to the uptoning, intensive axis identified in the contemporary profile of English JUST. Citations from the Oxford English Dictionary, which display uninterrupted overlap of but, only, right and very with JUST over the centuries and a shared trajectory from more concrete to more evaluative meanings, are the source to inform the onomasiological analysis in this section (a more detailed account of the diachronic development of the terms but, only, right and very is to be found in the appendix). The expression of possibility has not been included in the analysis, since it is a less salient reading within the semasiological contour of contemporary JUST only triggered by co-occurrence with terms that already convey possibility.

As displayed in Table 2, only and right overlap with JUST in the expression of downtoning, specificatory senses, while but and only intersect in the expression of restrictive and minimizing senses. In turn, right, very and but overlap with JUST in the uptoning expression of exactitude, while right, very and only do so in emphatic uses. According to the Oxford English Dictionary, the emphatic uses of right are now archaic in formal contexts, but they relate to the many intensive uses of the term in contemporary English (as in right on in American English or too right in British English) as well as to the use of adverb in context of adjectives such as smart, common practice since the $13^{\text {th }}$ century. When in context of prepositions and adverbs of place, the term right also overlaps with JUST in the expression of enthusiastic agreement, approval or encouragement. Other than this match, however, the notion of agreement is not shared by any of the terms within the onomasiological orbit of JUST, and none of them overlaps with JUST in the expression of politeness.

\begin{tabular}{|l|l|l|}
\hline \multicolumn{2}{|c|}{ MEANING NUANCES IN JUST TODAY } & \multicolumn{1}{c|}{ OVERLAPPING POLYSEMIES } \\
\hline \multirow{3}{*}{ DOWNTONING } & Specification of time and location & only - right \\
\cline { 2 - 3 } & Restriction & but - only \\
\cline { 2 - 3 } & Minimization & but - only \\
\hline \multirow{4}{*}{ UPTONING } & Exactitude & right - very - but \\
\cline { 2 - 3 } & Emphasis & right - very - only \\
\cline { 2 - 3 } & Politeness & \\
\cline { 2 - 3 } & Agreement & right \\
\hline
\end{tabular}

Table 2: $O E D$-based contemporary onomasiological map

In the main, this overlapping scenario is far from new. Already before the advent of JUST in English, the terms but, only, right and very were aligned around the two semantic axes that articulate the meaning of JUST today, namely, downtoning and uptoning. A comparison of the naming map prior to the introduction of the loanword displayed in Table 3 and the contemporary one displayed in Table 2 reveals a large degree of coincidence. As 
discussed above, the introduction of agreement within the senses expressed by right is noticeable, but other than this, no radical changes sever the early and contemporary onomasiological prospects, which only display a tendency towards increased overlap. According to Oxford English Dictionary data, the transition witnessed a number of minor developments: only but and but only became frequent downtoners from the late $15^{\text {th }}$ to the early $18^{\text {th }}$ centuries; the specificatory expression only just gained salience from the $17^{\text {th }}$ century; and but acquired restrictive meanings as an elliptic development from the conjunction shortly after the inception of the former use. The most significant innovation was the use of very as an emphatic adverb since 1530, once again a further exploitation of the former adjectival use obsolete as such since 1632, but still productive today in context of terms like same or opposite, where it overlaps with the intensive uses of JUST.

\begin{tabular}{|l|l|l|}
\hline \multicolumn{2}{|c|}{ MEANING NUANCES IN JUST TODAY } & \multicolumn{1}{c|}{ OVERLAPPING POLYSEMIES } \\
\hline \multirow{3}{*}{ DOWNTONING } & Specification of time and location & right \\
\cline { 2 - 3 } & Restriction & but - only \\
\cline { 2 - 3 } & Minimization & but \\
\hline \multirow{4}{*}{ UPTONING } & Exactitude & right - very \\
\cline { 2 - 3 } & Emphasis & right - very \\
\cline { 2 - 3 } & Politeness & \\
\cline { 2 - 3 } & Agreement & \\
\hline
\end{tabular}

Table 3: $O E D$-based onomasiological map prior to the introduction of JUST in English

The entrenchment of JUST in English is therefore surprising when considering that it entered the language to convey notions already expressed by competitors, which, far from being dropped from the language, have remained and still convey overlapping notions. To our mind, however, a comparison of the semasiological profile of JUST and its competitors reveals the presence of differential factors. On the one hand, JUST does not evaluate the value of the focus constituent as raking low, as opposed to other scalar particles such only or simply (Traugott, 1988:131). On the other, whereas the remaining terms aligned with the downtoning axis can only be downtoners and those aligned with the uptoning axis can only be uptoners, JUST can be both. Such bidirectional scalarity makes JUST cover the whole semantic spectrum and bridge the gap between both branches of the scalar gradient, hence accounting for the high salience of the term in the language. Over time, onomasiological coalescence with other terms within the domain might have enhanced the development of dormant readings at a faster pace than in other languages.

However, the expression of novel developments that remain largely unshared by other languages, notably the use JUST as a pragmatic marker for politeness and agreement, still remains unanswered. Is there something pertaining to the unshared notions that explains why they have not been grammaticalized to the same extent in other languages? Is it, as Traugott (1998:140) suggests, that "old meanings [...] continue to put constraints on the path of 
change, even though they may have lost their status as core meanings" and, as a result, staple readings ingrained within the internal semasiological profile of the term end up surfacing whatever may come? Neither semasiology nor onomasiology seem to provide conclusive answers, for the profile of JUST is largely alike in all languages and the terms that have diachronically interacted with JUST not include the notions that outstrip English from other languages. It might be argued that the unshared discursive readings do not belong to the prototypical core of the category, and as such, it is only natural they have not been activated in other contexts. It might also be argued that the reason for the contemporary divergence has to be the result of something which English does not share with other languages, namely the socio-historical framework.

The history of English has witnessed a major typological change from a semanticallyoriented language-type to a syntactically-oriented language-type. As a result of the loss of inflections (replaced by a rigid word order as a means of signalling relations), zero derivation or functional shift (by means of which a term belonging to a given word class can be used as another word class with no formal alteration) is typologically possible, and indeed frequent, in English, while impossible in most other languages. Because of the notable absence of endings in English, adjectival and adverbial readings are often blended into a single form, whereas in other languages two terms are often required for the purposes fulfilled by only one in English. This convergence may account for a condensation of uses in English which allows further developments not found in other languages. Nowadays, the debate on why cognate markers seem to develop in different ways in different languages is at the core of grammaticalization research (Aijmer \& Simon-Vandenbergen, 2003, 2004, 2006; Aijmer, Foolen \& SimonVandenbergen, 2006; Defour, D'Hondt, Simon-Vandenbergen \& Willems, forthcoming; Dostie, 2005; Lauwers, Vanderbauwhede \& Verleyen, 2010; Lorenz, 2002; Mosegaard Hansen, 2008; Mosegaard Hansen \& Strudsholm, 2008; Schwenter \& Traugott, 2000; SimonVandenbergen \& Willems, forthcoming; Swan \& Westvik, 1997), but much research is needed before conclusive reasons can be advanced.

In this respect, language contact is still relatively unexplored as a factor in language change (Brinton \& Traugott, 2005:159). In the case of English, intensive language contact over many centuries seems a plausible explanation for divergent trajectories and paces for development. At this point, it is worth recalling that JUST was introduced as a loanword from French at the very turn of the $15^{\text {th }}$ century. This is a time in which thousands of borrowings enter the language as a result of the triglossic situation of the Middle English period. As it is well known, external factors only accelerate processes already under way, that is, no external trigger can ever motivate a change the language is not ready to accept, so their significance should not be overstressed. However, the impact of increased language contact for an extended period of time cannot be understated either, and the speed with which changes have taken place in English is indeed a function of the linguistic and extralinguistic setting in which the language has evolved. In these circumstances, it is far from surprising that the 
semantic evolution of JUST has been faster in English than in other languages in which contact has never been so salient. At the same time, a very significant amount of language contact in English not only accounts for accelerated language change, but also for much more complex onomasiological scenarios, since the presence of loanwords in large amounts renders a much more polysemous word stock in which competition for semantic space is harder. For this reason, prototypicality effects are more likely in English than in other languages with less intricate onomasiological maps.

For all these reasons, it comes as no surprise that the semasiological profile of JUST is more complex in English than in other languages, even if similar grammaticalization and (inter)subjectification processes are taking place in all of them. One might wonder whether JUST in English is a forerunner or rather the odd-man-out. Although language change is unpredictable ("historical gradualness intersects with synchronic gradience but change cannot be read off from synchrony", Traugott, 2008), one might envisage a future in which, as grammaticalization proceeds, the semantic profile of JUST converges in different languages. However, full levelling does not seem entirely feasible, since the onomasiological complexity is greater in English than in other languages, and a more intricate departure point is likely to render a sustained breach between JUST in English and in other languages over time. In other words, English JUST might always be somewhat ahead of its counterparts, although the distance is likely to grow smaller and smaller over time. Will the readings which only exist in English emerge in other languages? Do the current developments in other languages allow anticipating the development of JUST as a pragmatic marker for agreement and politeness? How would these relate to the uses which are already being created in these languages? Within the expanding field of panchronic cross-linguistic research on pragmatic markers, "it is through comparison of partially parallel processes that the complex issues of actuation of a change and motivation for change become more transparent" (Simon-Vandenbergen \& Willems, forthcoming). Further evidence from various languages is therefore needed so as to provide a critical answer to the divergent evolution of cognate markers.

\section{CONCLUDING REMARKS}

Acknowledging the insufficiency of a range of approaches (panchronic, semasiological, onomasiological and cross-linguistic) to explain why in some languages the grammaticalization of cognate terms goes further and faster than in others demands further insights into the notion of context as a plausible explanation. This position is endorsed by Aijmer (2002:173), who claims that "in addition to its core meaning and discourse function, we need to consider the rhetorical context in which JUST is used". Likewise, Heine (2002: 97) claims that "a study of the various kinds of contexts is a sine qua non for understanding why existing meanings give rise to new meanings". However, it might be argued that, within linguistic theory, the context has been often regarded as a catalyst, i.e. something which 
enhances the start of a process and significantly reduces the amount of activation energy required to start a process, but without taking part in the process itself. Contextual features might indeed be regarded as a catalyst in polysemy in that, with an appropriate context, one particular reading from within an array of extant possibilities gets activated rather than others, whereas in instances without a context, such as the ones presented in the survey on JUST, the polysemy of the term makes informants start hesitating and considering a number of other possible readings. Thus, without a catalyst (without a context) a reading gets activated, but the process takes a long time and involves considerable hesitation (a lot of activation energy), whereas with a catalyst (with a context) the disambiguation of polysemy takes place much faster and without hesitation: a lot less activation energy becomes necessary to start the process of understanding.

However, claiming that the context does not take part in the process, as it happens with catalysts, is questionable, and it does not take into account the actual operation of the context in the rise of new grammatical meanings, sequenced (Heine, 2002:85) in a four-stage scenario. At stage 1, Heine claims, there is an expression with a "normal" or source meaning occurring in an array of different contexts. At stage II there is a bridging context giving rise to an inference to the effect that, rather than the source meaning, there is another meaning, the target meaning, offering a more plausible interpretation of the utterance concerned. At stage III, there is a new type of context, the switch context, which no longer allows for an interpretation in terms of the source meaning. Switch contexts may be viewed as a filtering device which rules out the source meaning. Finally, no longer being associated with the source meaning, the target meaning is now open to further manipulation: It is freed from the contextual constraints that give rise to it, that is, may now be used in new contexts. Heine refers to this situation as the conventionalization stage IV.

Before these stages can actually be applied to the explanation of the structure and behaviour of complex categories, so as to explain why some languages grammaticalize more and at a faster pace than others, an exhaustive typology of context, both internal, with an emphasis on suprasegmental patterns, and external, as a meaning trigger seems indispensable for grammaticalization studies. As claimed by Traugott (2008), by ingraining items within a set that frames developments in movement (a "set" still to be defined but most likely an analogical paradigm beyond the level of the clause), grammaticalization studies will be in a position to answer questions still open today. The description of JUST presented in this paper aims at contributing to the discussion by exploring aspects that may play a role in grammaticalization and have not received much attention so far. The foregoing insight into the various ways in which complex categories may be approached is thought to provide the basis for a better understanding of cognate pragmatic markers when contrasted with similar data from other languages. 


\section{ACKNOWLEDGEMENTS}

This work was supported by research funding by the Spanish Ministry of Education (grants DGICYTHUM-2005-08221-C02-0 and CCG07-UAM/HUM-1746). Thanks are due to Dirk Geeraerts and Augusto Soares da Silva for their insights into Dutch and Portuguese, and to the plurilingual subjects participating in the survey conducted at the Universidad Autónoma de Madrid. We also wish to thank the anonymous referees for their constructive feedback.

\section{REFERENCES}

Abraham, W. (Ed.). (1991). Discourse particles. Amsterdam: Benjamins.

Aijmer, K. (1985). Just. In S. Bäckman and G. Kjellmer, (Eds.) Papers on language and literature presented to Alvar Ellegård and Erik Frikman (pp. 1-10). Gothenburg.

Aijmer, K. (2002). English discourse particles: Evidence from a corpus. Amsterdam: Benjamins.

Aijmer, K. \& Simon-Vandenbergen, A.M. (2003). The discourse particle well and its equivalents in Swedish and Dutch. Linguistics, 41(6), 1123-1161.

Aijmer, K. \& Simon-Vandenbergen, A.M. (2004). A model and a methodology for the study of pragmatic markers: The semantic field of expectation. Journal of Pragmatics, 36, 1781-1805.

Aijmer, K. \& Simon-Vandenbergen, A.M. (Eds.). (2006). Pragmatic markers in contrast. Amsterdam: Elsevier.

Aijmer, K., Foolen, A. \& Simon-Vandenbergen, A.M. (2006). Pragmatic markers in translation: A methodological proposal. In K. Fischer (Ed.), Approaches to Discourse Particles (pp. 101-114). Amsterdam: Elsevier.

Andersen, H. (2001). Actualization and the (uni)directionality. In H. Andersen (Ed.), Actualization: Linguistic change in progress (pp. 225-248). Amsterdam: Benjamins.

Athanasiadou, A., Canakis, C. \& Cornilie, B. (Eds.). (2006). Subjectification: Various paths to subjectivity. Berlin: Mouton de Gruyter.

Bernárdez, E. (1995). Complexity and self-regulation processes in language. Paper given at ESSE, Glasgow University, United Kingdom, September.

Blakemore, D. (2002). Relevance and linguistic meaning: The semantics and pragmatics of discourse markers. Cambridge: Cambridge University Press.

Brinton, L. (1996). Pragmatic markers in English. Grammaticalization and discourse functions. Berlin: Mouton.

Cohen, G. (1969). How did the English word just acquire its different meanings? In R.I. Binnik, A. Davison, G.M. Green and J.L Morgan (Eds.) Papers from the $5^{\text {th }}$ regional meeting of the CLS (pp. 25-29). Chicago: Chicago Linguistic Society.

Davies, M. (2011). BYU-BNC: The British National Corpus. Retrieved from http://corpus.byu.edu/bnc/ on January, 1, 2011.

Defour, T., D'Hondt, U., Simon-Vandenbergen, A.M. \& Willems, D. (forthcoming a) In fact, en fait, de fait, au fait: A contrastive study of the synchronic correspondences and diachronic development of English and French cognates. Neuphilologische Mitteilungen.

Defour, T., D'Hondt, U., Simon-Vandenbergen, A.M. \& Willems, D. (forthcoming b) The cognates actually and actuellement: Diachronic developments from a cross-linguistic perspective. Languages in Contrast.

Dostie, G. (2004). Pragmaticalization et marqueurs discursifs: Analyse sémantique et traitement lexicographique. Brussels: De Boeck Duculot.

Erman, B. (1997). Guy's such a dickhead: The context and function of just in teenage talk. In U.B. Kotsinas, A.B. Stenström \& A.M. Karlsonn (Eds.) Ungdomsspråk $i$ Norden; Föredrag från ett forskarsymposium (pp. 96-100). Meddelanden från Institutionen för nordiska språk vid Stockholms universitet, MINS 43.

Fischer, K. (2000). From cognitive semantics to lexical pragmatics: The functional polysemy of discourse particles. Berlin: Mouton de Gruyter.

Fischer, K. (Ed.). (2006). Approaches to discourse particles. Amsterdam: Elsevier. 
Gibbs, R.W. \& Matlock, T. (2001). Psycholinguistic perspectives on polysemy. In H. Cuickens and B. Zawada (Eds.), Polysemy in cognitive linguistics (pp. 213-239). Amsterdam: Benjamins.

González, M. (2004). Pragmatic markers in oral narrative. Amsterdam: Benjamins.

Haken, H. (1977). Synergetics: An introduction. Berlin: Spriger.

Heine, B. 2002. On the role of context in grammaticalization. In I. Wischer and G. Diewald (Eds.), New reflections on grammaticalization (pp. 83-101). Amsterdam: Benjamins.

Jucker, A.H. \& Ziv, Y. (Eds.). (1998). Discourse markers: Descriptions and theory. Amsterdam: Benjamins.

Kishner, J. \& Gibbs, R.W. (1996). How just gets its meanings: Polysemy and context in psychological semantics. Language and speech, 39, 19-36.

König, E. (1991). The meaning of focus particles. A comparative perspective. London: Routledge.

Lauwers, P., Vanderbauwhede, G. \& Verleyen, S. (Eds.) (2010). Pragmatic markers and pragmaticalization: Lessons from false friends. Special Issue of Languages in Contrast, 10(2).

Lee, D.A. (1987). The semantics of just. Journal of Pragmatics, 11, 377-398.

Lee, D.A. (1991). Categories in the description of just. Lingua, 83, 43-66.

Leeman, D. (2004). L'emploi de juste comme adverbe d'énonciation. Langue Française, 142, 17-30.

Lenk, U. (1998). Marking discourse coherence. Functions of discourse markers in spoken English. Tübingen: Gunter Narr Verlag.

Lorenz, G. (2002). Really worthwhile or not really significant? A corpus-based approach to the delexicalisation and grammaticalisation of intensifiers in Modern English. In I. Wischer and G. Diewald (Eds.) New Reflections on Grammaticalisation. Amsterdam: Benjamins, pp. 49-68.

Martín-Zorraquino, M.A. and Montolío, E. (Eds.) (1998). Los marcadores del discurso. Teoría y análisis. Madrid: Arco Libros.

Mosegaard Hansen, M.B. (2008). Particles at the semantics/pragmatics interface: Synchronic and diachronic issues. Elsevier: Amsterdam.

Mosegaard Hansen, M.B. and Strudsholm, E. (2008). The semantics of particles: Advantages of a contrastive and panchronic approach. Linguistics, 46(3), 471-505.

Mossegaard Hansen, M.B. (1998). The function of discourse particles. A study with special reference to spoken standard French. Amsterdam: Benjamins.

Nevalainen, T. (1991). But, only, just. Focusing adverbial change in Modern English: 1500-1900. Helsinki: Société Néophilologique.

Pons, S. (2008). Introduction to the special issue on empirical data and pragmatic theory. Journal of Pragmatics, 40:8, 1353-56.

Portolés, J. (2001). Marcadores del discurso. Barcelona: Ariel.

Prigogine, I. (1983). ¿Tan solo una ilusión? Una exploración del caos al orden. Barcelona: Tusquets.

Schiffrin, D. (1987). Discourse markers. Cambridge: Cambridge University Press.

Schwenter, S. \& Traugott, E. (2000). Invoking scalarity: The development of in fact. Journal of Historical Pragmatics, 1(1), 7-25.

Siepmann, D. (2005). Discourse markers across languages. A contrastive study of second-level discourse markers in native and non-native texts with implications for general and pedagogic lexicography. London: Routledge.

Simon-Vandenbergen, A.M. and Willems, D. (forthcoming) Cross-linguistic data as evidence in the grammaticalization debate: The case of discourse markers. Linguistics.

Swan, T. \& Westvik, O.J. (Eds). (1997) Modality in Germanic languages: Historical and comparative perspectives. Berlin: Mouton de Gruyter.

Sweetser, E. (1990). From etymology to pragmatics. Metaphorical and cultural aspects of semantic structure. Cambridge: Cambridge University Press.

The Oxford English Dictionary on CD-Rom. (1994). ( ${ }^{\text {nd }}$ ed.). Oxford: Oxford University Press.

Thom, R. (1972). Stabilité structurale et morphogénèse. Paris: InterÉditions.

Traugott, E.C. (1988). Is internal semantic-pragmatic reconstruction possible? In C. Brooke-Rose, J. Fisiak \& T. Vennemann (Eds.), Rhetorica, phonologica, syntactica. London: Routledge, pp. 128-144.

Traugott, E.C. (1990). From less to more situated in language: The unidirectionality of semantic change. In S. Adamson, V. Law, N. Vincent and S. Wright (Eds.), Papers from the fifth ICEHL (pp. 497-517). Amsterdam: Benjamins. 
Traugott, E.C. (2008). Grammaticalization, pragmaticalization and/or (inter)subjectification: Methodological issues for the study of discourse markers. Rounding outline, Paper given at New Reflections on Grammaticalization 4 Conference, Leuven University, Belgium, July.

Traugott, E.C. \& Dasher, R.B. (2002). Regularity in semantic change. Cambridge: Cambridge University Press.

Wierzbicka, A. (1991). Cross-cultural pragmatics. The semantics of human interaction. Berlin: Mouton de Gruyter.

Wildgen, W. (1994). Process, image and meaning. Amsterdam: Benjamins.

\section{APPENDIX \\ DIACHRONIC DEVELOPMENT OF THE TERMS but, only, right, very}

BUT. According to the $O E D$, the functional range of the term but encompasses prepositional, adverbial and conjunctive facets. Both as a preposition and as an adverb, the term is mostly restricted to Scottish English, where it denotes the notion of outside (example 1), central in Old English but now dialectal or even obsolescent. From this reading and already in Old English, the preposition derived the (today obsolescent) sense without, apart from (example 2) and the sense except (example 3), undistinguishable from the conjunction after Old English times.

1. Mod. Sc. Gae BUT, and wait while I am ready.

2. 1423 JAS. I King's $Q$. viii, And doun I lay BOT ony tarrying.

3. a1000 Menolog. 87 (Gr.) Ymb first wucan BUTAN anre niht.

As a conjunction, but is highly productive today and displays a wide array of meaning nuances often borderline with adverbial uses. The earliest reading unless, if not (example 4), formerly preceded by a negative, dates back from Old English and was often strengthened by only from c1230 to 1715 . Slightly later in Old English, the most central reading of the conjunction but was developed, namely except (example 5).

4. 1393 LANGL. $P$. Pl. C. XX. 149 Alle pre nys BOTE a god.

5. a1000 Beowulf 705 (Z.) Ealle BUTON anum.

From this core reading, the semantic shift from a context such as nothing except a child towards no more than a child towards only a child is not difficult to infer, thus giving way to the adverbial reading merely at the very beginning of the fourteenth century, at first only in negative environments, as in he nis but a child, later on into he is but a child. Such an emphatic character accounts for the later development of the related reading exactly in the first quarter of the fifteenth century (example 6), often a mere expletive intersecting with just that would remain in the language until the second half of the nineteenth century.

6. 1662 MABBLE tr. Aleman's Guzman d'Alf. I. $248 \mathrm{He}$ is here (Sir) about the house, I saw him BUT now.

All in all, the term but reflects the intricacy of its historical development both in its recurrent semantic overlap with other terms within the constellation (only and just in particular) and in its changing collocational patterns. As such, the conjunction but is often found in early texts in (typically negative) clauses where another term would be used today (examples 7-13):

7. $c 1500$ Rob. Hood (Ritson) I.i.155, I have no more BUT ten shillings (instead of PDE than)

8. 1597 T. BEARD Theat. God's Judgem. (1612) It was no sooner said BUT done (instead of PDE than)

9. 1727 DEFOE Secrets Invis. World (1840) 236 He had not gone many steps more, BUT he saw his brother (instead of PDE before or when) 
10. 1525 LD. BERNERS Froiss. II. 156 It was not longe after BUT that the duke of Lancastre... (instead of PDE that alone)

11. 1790 PALEY Horce Paul. I. 5, I cannot deny BUT that it would be easy (instead of PDE that alone)

12. 1832 CARLYLE in Fraser's Mag. V. 399 Who doubted BUT the catastrophe was over? (instead of PDE that)

13. 1822 F. PAGET Tales Village Childr. Ser. II. (1858) She cannot miss BUT see us (instead of PDE -ing)

As for the overlap with other terms within the constellation, the conjunction but has historically been often found in context of the term only, the latter strengthening but when meaning unless (example 14), or rather emphasized by it (from 1477 to 1644) when meaning merely in contexts where only would now be used alone (example 15), as well as in PDE sentences such as the only person I have met but you.

14. $c 1460$ FORTESCUE Abs. \& Lim. Mon. (1714) 42 It nedith not to..purvey, BUT ONLY for the Kyngs Hous.

15. 1644 Milton Areop. (Arb.) 36, I find BUT ONLY two sorts of writings.

At the same time, but has been found to express the reading merely, hence intersecting with the term just, with which it also intersects in expressing exactly (as in but now meaning just now in example 6), a reading also shared by the terms right and very at some point.

ONLY. According to the $O E D$, the term only was present in the language already in Old English, with a reading obsolete since the beginning of the seventeenth century, namely specially (example 16). From this reading, the sense exclusively (prototypical today) would spring at the very beginning of the thirteenth century (example 17). From the beginning of the fifteenth to the beginning of the nineteenth centuries, this reading was complemented with the related sense by or of itself alone (example 18).

16. 1554 RIDLEY Wks. (Parker Soc.) 370 In them whom they ONLY esteemed for their priests and sages.

17. a1297 R. GLOUC. (Rolls) 1513 Pe king louede is wif..so vaste pat al is herte ONLICHE on hire on he caste.

18. a1555 PHILPOT Exam. \& Writ. (Parker Soc.) 66 Master doctor hath affirmed that these words..spoken by the priest, ONLY do make the Sacrament.

The overlap of only with other terms within the constellation is attested by an expression such as only just, meaning at a time no farther than the immediate past (as in I have only just received it), which exists in the language ever since 1676. The interface is also attested by the expressions only but and but only (examples 19 and 20), meaning either merely or except, now obsolete but present in the language from 1478 to 1711 . Not in context of any of the terms under study, but certainly within the semantic sphere here considered, is the expression only for meaning except (example 21), which has been present in the language since the mid-sixteenth century. Moreover, in prototypically expressing the reading exclusively, the adverb only intersects with the semantic sphere of the term just.

19. 1478 Paston Lett. III. 232 Paid..for the tythynges, ONDELY BUT in corne whan it was inned in to the barn.

20. 1605 Chapman All Fooles Wks. 1873 I. 180 Now here all are pleas'd, ONELIE BUT Cornelio.

21. 1664 PePYs Diary 22 Apr., My wife and I, in their coach to Hide Parke, where..pleasant it was, ONLY FOR the dust.

RIGHT. According to the $O E D$, the adverb right has been present in the language since Old English, at that time meaning (i) properly, (ii) straight in a direct course and (iii) exactly. The reading properly (example 22) is still alive, as well as the related nuance in accordance with justice (example 23). 
22. 1693 LOCKE Educ. $\S 160$ The first thing should be taught him is to hold his Pen RIGHT.

23. 1611 BIBLE Ps. ix. 4 Thou satest in the throne iudging RIGHT.

The reading straight in a direct course (example 24) has also been highly salient from the earliest times and conducive to the creation of related readings through invited inference. As such, the development of the sense all the way to (example 25) in the twelfth century soon gave rise to an intensifying reading in the thirteenth century (example 26), now archaic in formal contexts but related to the many intensive uses of the adverb in contemporary American English and Black Vernacular English. In turn, the reading straight in a direct course gave rise in the fourteenth century to the reading in the proper course (example 27), which links up with the moral readings having to do with properness.

24. $c 1205$ LAY. 1395 Heo ferden from Spaine RIHT toward Brutaine.

25. 1667 MiLTON P.L. x. 398 You two this way..RIGHT down to Paradise descend.

26. 1399 LANGL. Rich. Redeles Prol. 16 Thus tales me troblid..And amarride my mynde RIHT moche.

27. 1611 BIBLE Ecclus. Xlix. 9 He..directed them that went RIGHT.

Another semantic facet of the term that links up with the notion of properness is that of accuracy (example 28), which springs from the reading exactly (example 29), also present since Old English times and related to other terms within the broader onomasiological picture. The reading exactly as such (in Middle English poetry sometimes a mere rime-tag) is nowadays obsolescent, although not for indicating exact time or location (example 30). In turn, the expression of immediacy was developed already in Old English out from that of exact time in context of terms such as after, away, now or off (example 31).

28. c1000 Ags. Gosp. Luke x.28 मа cwæð he, 'RIHTE pu andswarodest'.

29. c1386 CHAUCER prol. 804, I wol my self goodly with yow ryde RIGHT at myn owene cost.

30. a1225 Ancr. R. 54 Heo pet was RIHT po imaked mid Godes honden.

31. $c 1200$ ORMIN 2799 RIHHT after patt tin greting word Wass cumenn i min ære.

32. $c 1200$ ORMIN 5563 Pe sexte zife off Haliz Gast Iss an RIGHHT god reowwsunge.

Besides, an emphatic extension of reading exact is common in US slang (with prepositions and adverbs of place) for denoting enthusiastic agreement, approval or encouragement, as in the expression right on! This use is related both to the intensifying nuance developed out from the straight in a direct course reading and to the use of the term as an uptoner in context of adjectives (such as in right smart), originated in the thirteenth century (example 32) and typically US today. All in all, the term right has been found to express the notions of properness, straightness and exactness (into proximal future), in all cases pointing towards uptoning and emphatic uses that intersect with the semantics of just. As a matter of fact, as Traugott (1988:140) points out, at the time when just first entered English, derivates of native right, which goes back to Old English and beyond to Germanic, sometimes alternate in manuscripts with just. The difference between both terms may reside in that "right never developed the range of uses of a scalar particle, being limited mainly to spatial and temporal adverbial constructions ... Apparently it is this meaning [having to do with straightness and boundaries ... associated with paths and orientation towards some goal] that in part constraints the uses of right and helps to maintain the differences with just, despite neutralization in some contexts. The original meaning of right can be hypothesized to account for the fact that right can be an intensifier (meaning 'very') but not a downtoner ... Whereas just excludes more (as well as less), right in its linear, directed sense invites the inference that more is possible" (Traugott 1988:141)

VERY. According to the OED, the adjective very was borrowed from French around 1250 with the meaning truly or properly so called (example 33), a common reading from the fourteenth to the seventeenth centuries, but now rare except as an echo of Biblical usage (a single example has been attested for the noun very, meaning truth: 1382 Wyclif Rom. Prol., Thes reuokith the apostle to the VERREY [1388 treuthe] and the gospels bileue). The same dates (fourteenth to seventeenth centuries) 
mark the lifespan of the sense truthful, rightful (example 34), the earliest semantic development out from the original meaning, and which is obsolete today but related to readings with which the term is associated in PDE.

33. $c 1400$ MANDEVILLE (Roxb.) xv. 66 He..es a haly prophete and a VERRAY in worde and in dede.

34. 1303 R. BRUNNE Handl. Synne 9965 Pese wurdes are VERRY and clere; Dauyd hem seyth yn pe sautere.

As such, the concept of truth is present in the early contexts which frame the transition towards the reading real (example 35), originated towards the end of the fourteenth century. From this sense, emphatic (example 36) and intensive, uptoning (example 37) uses of the term were soon developed. In turn, the shift towards the expression of exactness (example 38) is not difficult to predict out from a combination of the notions of truth and emphatic exactness.

35. 1387 TREVISA Higden (Rolls) I. 255 Ysidre seip pat VERRAY [L. proprie dicta] Germania hap in pe est side pe mouth of pe river Danubius.

36. 1711 STEELE Spect. No. $157 \mathbb{P} 1$ Marius was then a VERYE boy.

37. 1609 Holland Amm. Marcell. 166 From the VERY brims of Tigris banke, as farre as to Euphrates, there was no greene thing left.

38. $c 1391$ CHAUCER Astrol. i. $\S 17$ Euermo this cercle equinoxial turnyth Iustly fro verrey est to VERREY west.

Adverbial uses of right are a later development out from the adjective. The semantic evolution of the adverb, present in the language since the early fourteenth century, mirrors that of the adjective in the inception of the intensive readings with which the term is prototypically associated today. As such, departing from the reading truthfully (example 39), obsolete since the end of the fifteenth century, the adverb would develop emphatic uses (example 40) at the same time in which the connection with the notion of truth fades. The subsequent shift towards purely intensive uses (example 41) would emerge at the turn of the sixteenth century.

39. c1485 Digby Myst. (1882) II. 357 The compiler here-of shuld translat VERAY so holy a story.

40. a1578 LindeSAY (Pitscottie) Chron. Scot. (S.T.S.) I. 4 To pray me think it is VERRAY necessarie.

41. 1644 GataKer Disc. Apol. 17 This fel out to be the VERIE next day after Qeen Elizabeths decease.

Shortly afterwards, the adverb very would come to denote the notion of exactness (example 42), a reading which is obsolete as such since 1632, but which is still productive in context of terms like same or opposite, where it overlaps with (and sometimes is even undistinguishable from) purely intensive uses (example 43), indeed productive today.

42. 1530 PALSGR. 823/2 VERY here, VERY ther, droit cy, droit la.

43. 1835 T. MitChELL Acharn. Of Aristoph. 609 The VERY opposite word was of course expected.

Hence, right overlaps with just in the expression of the notion of emphasis, at times borderline with that of exactness. As Traugott (1988:141) puts it, "another lexical item which shares some semantic (but not syntactic) properties with scalar just is very as in that's the very spot on which he stood. Here, very, like just, specifies a unique referent among a set of alternatives. In other uses, very identifies an extreme on a scale, as in the very back of the room ... or intensity, as in she is very tall ..., but it cannot place a referent on the lowest or negative end of the scale. That is, it cannot be a downtoner, just an uptoner. Again, as in the case of right, we can invoke the original meaning: very derives from MF verray 'true' and ... still shares many properties with true/truly. As such, it would hardly be expected to mean 'barely, merely". 